Original paper

\title{
Survey on Post-Disaster Timelines Following a Large-Scale Disaster Expected to Occur in the Near Future for Pre-Disaster Recovery Planning
}

\author{
Yu Matsubara ${ }^{1^{*}}$ and Katsuya Yamori ${ }^{2}$
}

Received: 29/12 /2020 / Accepted: 30/04/2021 / Published online: 23/09/2021

\begin{abstract}
The limitation of resources for post-disaster recovery after a large-scale disaster is a global problem. It is difficult to restart all activities simultaneously, so it is critical to determine when diverse social and economic activities should resume, called a post-disaster timeline (PDT). We surveyed PDTs in Aichi Prefecture, which is the most industrialized prefecture in Japan and, therefore, economically important. The results revealed differences in PDTs according to sex, occupation, and reference group (the main group the respondent had in mind when answering questions, such as Japan, Aichi Prefecture, and the disaster-affected area). We estimated PDTs for Aichi Prefecture as a whole and determined what kind of activities are socially acceptable even in the earlier stages of recovery. In pre-disaster recovery planning, it is critical to build consensus by considering the differences in PDTs among different groups of people. Furthermore, when a disaster occurs, PDTs in the disaster-affected prefecture as a whole and the existence of people with different PDTs should be taken into account.
\end{abstract}

Keywords: post-disaster timelines, pre-disaster recovery planning, social norms, economic recovery, consensus building,

\section{INTRODUCTION}

Pre-disaster recovery planning is important for achieving better recovery and reconstruction outcomes, and currently, many areas in Japan are engaged in such efforts. This planning

\footnotetext{
${ }^{1}$ Graduate School of Informatics, Kyoto University

*Corresponding author Email: matsubara.yu.73n@st.kyoto-u.ac.jp

${ }^{2}$ Disaster Prevention Research Institute, Kyoto University
} 
involves beginning to plan for recovery during the pre-disaster phase (Otsuyama and Maki 2018). The Japanese government has published guidelines on this practice (Ministry of Land, Infrastructure, Transport and Tourism 2018). However, such guidance focuses mainly on medium- to long-range city planning, not on short- to medium-range activities for recovery. We need to develop another guideline on pre-disaster recovery planning focusing on short- to medium-range activities for recovery.

Citizen participation is also important for recovery and reconstruction efforts ${ }^{(1)}$. After a disaster occurs, collecting public opinions and building consensus often takes a long time which ultimately causes an unbeneficial delay in implementing recovery activities. However, because the recovery process greatly impacts the lives of local residents, it is critical to prepare a means by which their opinions, especially those on short- to medium-range recovery efforts, can be collected and taken into consideration. The guideline on pre-disaster recovery planning focused on short- to medium-range activities for recovery needs to refer to effective ways of citizen participation to create the plan.

Against this backdrop, we have begun to prepare a short- to medium-range pre-disaster recovery plan in our study area ${ }^{(2)}$, Aichi Prefecture, Japan. Aichi Prefecture is at risk of a magnitude 8-9 earthquake along the Nankai megathrust, the fault running under the Nankai Trough off the southeastern coast of Japan (Aichi Prefectural Government 2014). There is a $70 \%-80 \%$ possibility of a Nankai megathrust earthquake in the next 30 years (Ministry of Education, Culture, Sports, Science and Technology 2020), and the study area is at high risk of severe damage from such an event (Aichi Prefectural Government 2014). Aichi Prefecture is an economically important area in Japan because it is home to one of the largest car manufacturing companies in the world and its suppliers ${ }^{(3)}$. Therefore, it is necessary to plan a recovery strategy to realize a quick economic recovery in this area ${ }^{(4)}$. The results of a survey conducted in 2020 of 2,000 people affected by the 2011 Great East Japan Earthquake revealed that only $17.7 \%$ of the respondents felt that "the local economy has recovered from the earthquake" (NHK 2020). This result also indicates the importance of a quick and effective economic recovery strategy. It is important to discuss economic recovery in short- to mediumrange pre-disaster recovery planning.

In contrast, search and rescue activities, humanitarian logistics, shelter operations, restoration of lifelines, and providing temporary housing are all deemed necessary after a largescale earthquake. If we know when local people accept activities aimed at economic recovery without public backlash, discussions on pre-disaster recovery planning become easier to promote. This paper uses the term post-disaster timeline (PDT) to describe the timing for when to restart diverse social and economic activities following a disaster.

There is a good example of the importance of PDTs. The Niigata-Chuetsu-Oki earthquake occurred on July 16, 2007, off the western coast of Niigata Prefecture. Water service was suspended after the earthquake in Kashiwazaki city. It took nearly three weeks to restore all the water supply systems (Japan Water Works Association 2008). Still, the city's water supply 
for an economically important factory was restored just one week after the earthquake, on July 23 (Ministry of Economy, Trade and Industry 2018). Because the factory was producing an essential component for the automobile industry and many related companies supported the factory's reopening, the city prioritized restoring water service to the factory. However, elsewhere in the city, the water restoration rate on July 23 was only around 50\% (Ministry of Health, Labour and Welfare 2007). This means that many people were without water at that time. In this city, the mayor's decision to prioritize an economically important factory in the earlier stages of recovery was accepted by local residents, but in other cities, there may be a risk of public backlash. Therefore, it is important to know when such actions will become acceptable in the affected area.

When we discuss PDTs, it is important to consider the practical and strategic aspects involved and the priorities of various stakeholders concerning diverse social and economic activities. We must also determine how much of each resource - time, money, energy, supplies, and personnel — can be allocated to each activity during the recovery phase. However, it is equally important to consider social psychological perspectives. For example, as of the writing of this paper, the COVID-19 pandemic is ongoing, and there is a general sentiment that more resources should devote to preventing the spread of infection rather than using resources for other issues. In Japan, a government-subsidized domestic travel campaign was widely criticized. Common people, scholars and even business owners argued that the government should channelize the financial resources for public health efforts to curtail the spread of COVID-19 (AERA 2020; The Asahi Shimbun 2020a, 2020b). Given that society has not experienced a pandemic like the COVID-19 in a century, it is impossible to collect enough data to perform a cost-benefit analysis to determine the most practical policies to implement. Such criticism is not so much a comment on evidence-based practical strategy but rather on social norms concerning what should be prioritized. In this kind of situation, people are more likely to rely on what others think - social norms - rather than their own thoughts or ideas. People try harder to read public sentiment in such unprecedented times when assessing what kind of recovery activities should be prioritized unless they have their own strong preference. Put another way, assumed social norms influence what actions people take. Therefore, it is important to know PDTs in the study area from a social psychological perspective for predisaster recovery planning. We designed our survey from this viewpoint, asking respondents to think about what social norms would be like following a disaster, rather than giving their own subjective views on what actions should be taken and what is in order ${ }^{(5)}$. (We present the questionnaire survey items in the Methods section.)

Previous studies have investigated individual psychological changes following a disaster. Kimura (2007) proposed a recovery-and-reconstruction calendar and revealed the psychological changes in individuals affected by a disaster through questionnaire surveys. Miyamoto and Atsumi (2011) conducted interviews with disaster-affected individuals and asked them to describe a curve, which they call a revitalization curve, showing their psychological state since the disaster occurred. Other studies have tried to generalize individual psychological changes after a disaster. Bryant (2006) focused on a timeline of mental health 
care after a disaster, and Tanaka et al. (1999) considered the changes in the mental state of disaster-affected individuals based on their actions following the disaster. Solnit (2010) focused on social norms in studying the community spirit that arises following a disaster. According to the authors' knowledge, there is no comprehensive study on post-disaster social norms of an imminent earthquake. Therefore, this study aims to identify PDTs in a specific area from the social psychological perspective by conducting a survey and evaluating whether the survey method is appropriate for finding a methodology of pre-disaster recovery planning focusing on short- to medium-range activities for recovery.

\section{METHODS}

The questionnaire survey was conducted online with 750 residents of Aichi Prefecture using the Internet. Although a survey of private firms is important when considering economic recovery, we first focused on residents in the area to investigate social norms and the possibility of public backlash in response to government actions aimed at disaster recovery.

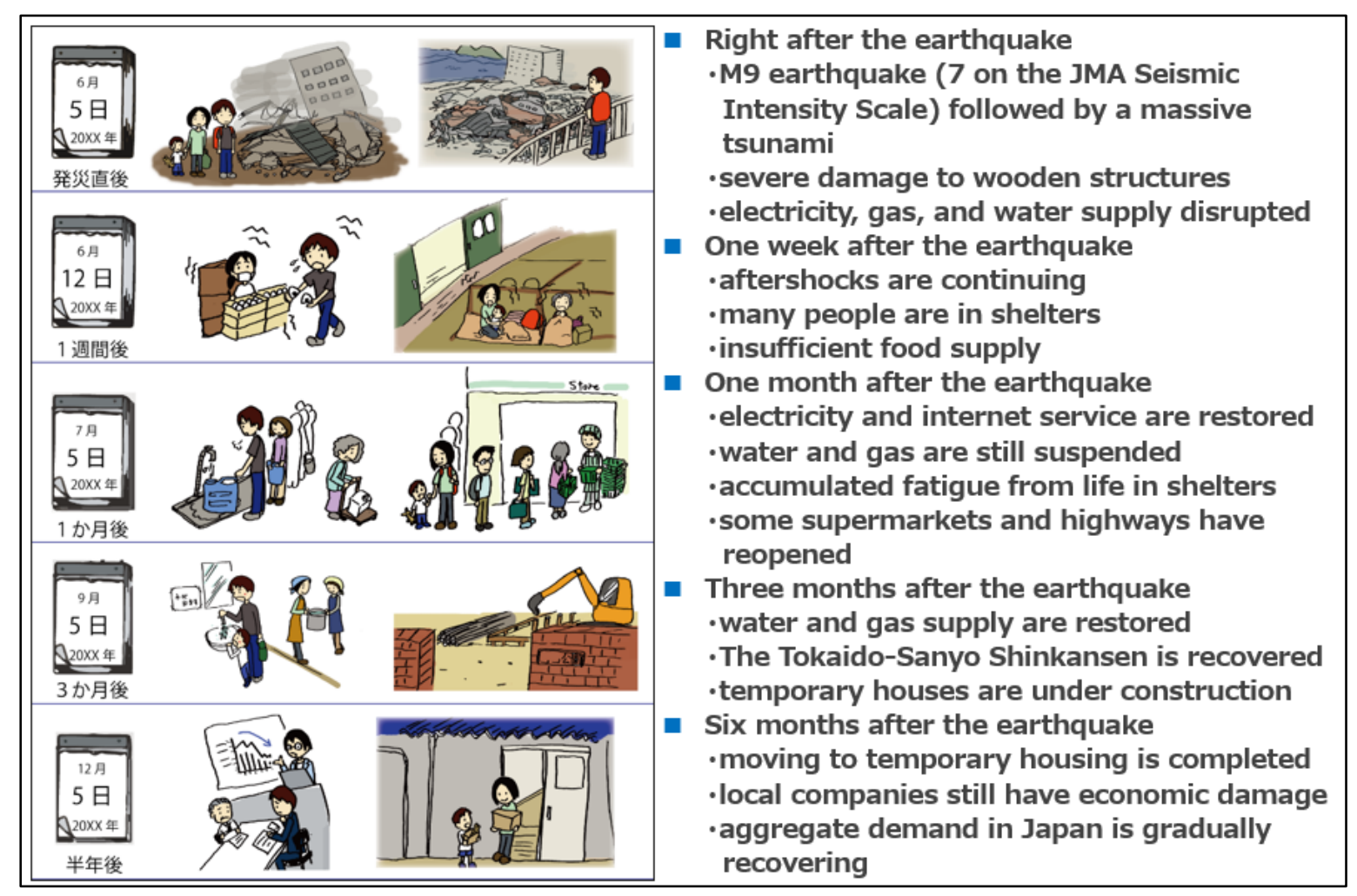

Figure 1. Outline of the hypothetical scenario of the disaster 
In the questionnaire, we provided a hypothetical scenario of a disaster. We then asked whether various activities would be socially acceptable at each of the listed time points following the disaster. The disaster scenario was written based on the Nankai megathrust earthquake that is anticipated by the Japanese government (Central Disaster Management Council 2013; Cabinet Office 2019). It included an illustration to help respondents more quickly understand the outline of the scenario. Figure 1 shows the outline of the scenario.

The question is "Suppose you are now facing the large-scale earthquake disaster described in the following hypothetical scenario. When do you think it would be acceptable to start the activities listed below? For each activity, check only one time point (of the six choices). After that time point, the activity will be considered socially acceptable. Please answer based on your perception of public sentiment rather than your own personal opinion" (Hereinafter, we refer this as 'main question'). The six choices were - "right after the earthquake," "1 week after the earthquake," "1 month after the earthquake," "3 months after the earthquake," "6 months after the earthquake," and "more than six months after the earthquake."

We included 32 activities based on the following research below. We performed a literature survey of past large-scale earthquake disasters in Japan, including a comprehensive review of the 1995 Great Hanshin Earthquake (National Land Agency 1999), an analysis of the media news and the public's response (Yamanaka 2005), an economic recovery report from the 2016 Kumamoto earthquakes (Ito and Kashima 2018), an analysis of television commercials after the 2011 Great East Japan Earthquake (Kamei 2011), and so on. We also obtained information from several individuals who had experienced an earthquake disaster and local government officials and private firms in Aichi Prefecture. We extracted those activities that seemed to be important from these information sources. Because we wanted to know when to prioritize activities related to economic recovery, we prepared equal numbers of economic and noneconomic activities (Table 1). We included activities that were not directly related to disaster recovery because they also give us information about social norms after a disaster.

We aimed to sample the same numbers of respondents in three different areas of Aichi Prefecture, as shown in Table 2, in order to determine whether there are any differences in thinking about PDTs according to location and occupation. The three areas were those recognized by the Aichi Prefectural Government (2020). The names of the areas are Owari, Nishi-Mikawa, and Higashi-Mikawa. Owari locates in the west part of Aichi Prefecture and is the most populated area. Nishi-Mikawa locates in the middle part of the prefecture and is the most industrialized area. Higashi-Mikawa locates in the east part of the prefecture and is a comparatively rural area. All three areas are supposed to be hit and severely damaged by a Nankai megathrust earthquake and tsunami (Aichi Prefectural Government 2014). Occupation categories are public employees, including government officials, company employees, fulltime workers, and executives, including part-time workers, self-employed individuals, nonworking spouses, the unemployed, and students. 
Table 1. Post-disaster activities included in the survey

\begin{tabular}{|c|c|}
\hline Economic activities & Non-economic activities \\
\hline Commercials are broadcast on television. & $\begin{array}{l}\text { A celebrity uploads photos of their elaborate } \\
\text { birthday party on social media. }\end{array}$ \\
\hline $\begin{array}{l}\text { Local economic federations submit a letter of } \\
\text { request for support with economic recovery } \\
\text { activities to the government. }\end{array}$ & $\begin{array}{l}\text { A TV station in Tokyo broadcasts a program } \\
\text { on the likelihood for Tokyo to be struck by an } \\
\text { earthquake in the near future. }\end{array}$ \\
\hline $\begin{array}{l}\text { A tourism campaign for affected areas is } \\
\text { launched. }\end{array}$ & Disaster-related trash collection service ends. \\
\hline $\begin{array}{l}\text { A waterworks bureau prioritizes the restoration } \\
\text { of water service to an economically important } \\
\text { area. }\end{array}$ & $\begin{array}{l}\text { Local governments close small shelters, and } \\
\text { the residents there are asked to move to a } \\
\text { larger shelter. }\end{array}$ \\
\hline $\begin{array}{l}\text { A major firm in the area requests earlier repair } \\
\text { works of the approaching roads to the company's } \\
\text { site. }\end{array}$ & $\begin{array}{l}\text { Individuals sheltering in school classrooms are } \\
\text { asked to move to the gym by the local } \\
\text { government in order to resume the classes. }\end{array}$ \\
\hline $\begin{array}{l}\text { The prime minister calls for the quick restart of } \\
\text { automobile exports. }\end{array}$ & $\begin{array}{l}\text { Local governments hold an election for } \\
\text { members of the prefectural assembly. }\end{array}$ \\
\hline $\begin{array}{l}\text { Volunteer groups begin to help not only affected } \\
\text { households but also affected firms. }\end{array}$ & $\begin{array}{l}\text { Local governments hold workshops to develop } \\
\text { the city's reconstruction plan. }\end{array}$ \\
\hline Pachinko parlors reopen. & $\begin{array}{l}\text { Broadcasting of comedy shows on television } \\
\text { resumes. }\end{array}$ \\
\hline $\begin{array}{l}\text { Local governments end the free distribution of } \\
\text { food and daily necessities at shelters. }\end{array}$ & $\begin{array}{l}\text { The prime minister makes a state visit to a } \\
\text { foreign country. }\end{array}$ \\
\hline $\begin{array}{l}\text { Local governments reduce the number of } \\
\text { officers for shelters and local residents and } \\
\text { reassign them to assist with economic recovery } \\
\text { efforts. }\end{array}$ & $\begin{array}{l}\text { The provision of food and bathing facilities by } \\
\text { the Self-Defense Forces ends. }\end{array}$ \\
\hline $\begin{array}{l}\text { A major firm in the area engages in business } \\
\text { with a company in another area rather than a } \\
\text { local company to resume normal operations } \\
\text { more quickly. }\end{array}$ & $\begin{array}{l}\text { Local governments issue an alert for typhoons } \\
\text { and heavy rains in their local newsletter. }\end{array}$ \\
\hline $\begin{array}{l}\text { A major firm decides to leave the affected area } \\
\text { to resume normal operations more quickly. }\end{array}$ & $\begin{array}{l}\text { Interviews of disaster-affected individuals are } \\
\text { conducted to learn lessons of from the disaster. }\end{array}$ \\
\hline $\begin{array}{l}\text { A manufacturing company asks all its } \\
\text { employees to return to work. }\end{array}$ & $\begin{array}{l}\text { A charity music festival is held to lift the } \\
\text { spirits of disaster-affected individuals. }\end{array}$ \\
\hline $\begin{array}{l}\text { Automotive dealerships launch a sales } \\
\text { promotion campaign. }\end{array}$ & $\begin{array}{l}\text { Governments reduce the number of people } \\
\text { working to find missing persons. }\end{array}$ \\
\hline $\begin{array}{l}\text { A company makes large-scale personnel changes } \\
\text { (such as transfers or layoffs). }\end{array}$ & $\begin{array}{l}\text { A professional baseball game is held in the } \\
\text { affected area. }\end{array}$ \\
\hline $\begin{array}{l}\text { Construction of the Linear Chuo Shinkansen } \\
\text { maglev line resumes. }\end{array}$ & $\begin{array}{l}\text { Local governments finalize the city's } \\
\text { reconstruction plan. }\end{array}$ \\
\hline
\end{tabular}


Table 2. Sampling plan

\begin{tabular}{|l|c|c|c|c|}
\hline & Owari area & $\begin{array}{c}\text { Nishi-Mikawa } \\
\text { area }\end{array}$ & $\begin{array}{c}\text { Higashi-Mikawa } \\
\text { area }\end{array}$ & Total \\
\hline Public employee & 50 & 50 & 50 & 150 \\
\hline Company employee & 100 & 100 & 100 & 300 \\
\hline Others & 100 & 100 & 100 & 300 \\
\hline Total & 250 & 250 & 250 & 750 \\
\hline
\end{tabular}

After the main question, we asked, "In the main question, we asked you to answer based on your perception of public sentiment. As the meaning of 'public,' which one did you mainly imagine?" We set five choices for this question: Japan, the disaster-affected area, Aichi Prefecture, one's local community, and others. We considered that the idea of a 'reference group' had been emphasized in previous social psychological theories (Shibutani 1955). A reference group is one that people think of when they perceive or assess social norms. (Shibutani (1955) discusses there are three types of usage of this term: (1) groups which serve as comparison points; (2) groups to which men aspire; and (3) groups whose perspectives are assumed by the actor. In this paper, we use this term as the meaning of (3).) Reference groups are considered critical in shaping social norms and the impacts of social norms on individuals. Reference groups can range in size from families to classes in schools, local communities, cities, states, nations, and even the entire world. The purpose of the question above is to reveal the reference groups of the respondents.

We also asked respondents to inform their sex, age, household members (including whether there are young children less than six years old or elderly relatives 65 years of age or older), household income, and experience staying in a shelter for more than one night.

\section{RESULTS}

\subsection{Sampling results}

The survey was conducted from August 21 to 24, 2020, and samples were obtained according to the plan shown in Table 2 . The age and sex distributions of the samples are shown in Tables 3 and 4. 
Table 3. Distribution of age

\begin{tabular}{|c|c|}
\hline Under 20 & 2 \\
\hline $20 \mathrm{~s}$ & 73 \\
\hline $30 \mathrm{~s}$ & 145 \\
\hline $40 \mathrm{~s}$ & 205 \\
\hline $50 \mathrm{~s}$ & 188 \\
\hline $60 \mathrm{~s}$ & 109 \\
\hline $70 \mathrm{~s}$ & 27 \\
\hline $80 \mathrm{~s}$ and older & 1 \\
\hline Total & 750 \\
\hline
\end{tabular}

Table 4. Distribution of sex

\begin{tabular}{|c|c|}
\hline Male & 497 \\
\hline Female & 251 \\
\hline Others & 2 \\
\hline Total & 750 \\
\hline
\end{tabular}

\subsection{Differences between groups based on respondent attributes}

First, we looked for differences in responses to the main question between groups. We created the groups based on differences in respondent attributes and used the chi-squared test to compare them. The tested groups were as follows ${ }^{(6)}$.

- Location- between Owari and Nishi-Mikawa, between Owari and Higashi-Mikawa, and between Nishi-Mikawa and Higashi-Mikawa

- Occupation- between public employees and company employees, between public employees and others, and between company employees and others

- Age- between those in their 50s and younger and those in their 60s and older

- Sex- between males and females

- Household groups - between households with young children or/and elderly relatives and those without

- Household income- between those earning less than 5 million yen and those earning 510 million yen, between those earning less than 5 million yen and those earning more than 10 million yen, and between those earning 5-10 million yen and those earning more than 10 million yen

- Reference group- between Japan and the disaster-affected area, between Japan and Aichi Prefecture or one's local community, between the disaster-affected area and Aichi Prefecture or one's local community 
We also wanted to investigate differences according to the experience of staying in a shelter for more than one night. Still, we were unable to obtain a sufficient number of samples for the chi-squared test.

The results of the chi-squared tests are shown in Table 5. We conducted tests for all 32 activities listed in Table 1, and thus the maximum number of statistical differences is 32 . We checked that cells with expected values of less than five did not account for more than $20 \%$ of the data (Cochran's rule).

Table 5. Number of statistical differences between the groups

\begin{tabular}{|c|c|c|c|c|}
\hline \multicolumn{2}{|r|}{ Groups } & $\mathrm{p}<0.1$ & $\mathrm{p}<0.05$ & $\mathrm{p}<0.01$ \\
\hline \multirow{3}{*}{ Location } & Owari and Nishi-Mikawa & 6 & 3 & 1 \\
\hline & Owari and Higashi-Mikawa & 7 & 5 & 1 \\
\hline & Nishi-Mikawa and Higashi-Mikawa & 6 & 4 & 0 \\
\hline \multirow{3}{*}{ Occupation } & Public employees and company employees & 1 & 1 & 0 \\
\hline & Public employees and others & 22 & 16 & 7 \\
\hline & Company employees and others & 15 & 12 & 7 \\
\hline & Age $(<59,>60)$ & 8 & 2 & 1 \\
\hline & Sex (male, female) & 24 & 21 & 12 \\
\hline \multicolumn{2}{|c|}{ With young children or/and elderly relatives and without } & 2 & 2 & 0 \\
\hline \multirow{3}{*}{$\begin{array}{c}\text { Household } \\
\text { income }\end{array}$} & $<5$ million yen and $5-10$ million yen & 2 & 2 & 0 \\
\hline & $<5$ million yen and $>10$ million yen & 3 & 1 & 0 \\
\hline & $5-10$ million yen and $>10$ million yen & 4 & 4 & 0 \\
\hline \multirow{3}{*}{$\begin{array}{c}\text { Reference } \\
\text { group }\end{array}$} & Japan and the disaster-affected area & 32 & 32 & 31 \\
\hline & Japan and Aichi Prefecture or one's local community & 31 & 31 & 25 \\
\hline & $\begin{array}{l}\text { The disaster-affected area and Aichi Prefecture or } \\
\text { one's local community }\end{array}$ & 2 & 1 & 0 \\
\hline
\end{tabular}

We found relatively many statistical differences between occupations, sexes, and reference groups. In contrast, the statistical differences between the locations, ages, household members, and household incomes were relatively small. We checked the relationships between occupations, sexes, and reference groups. We found some correlation between sexes and occupations and between occupations and reference groups. Still, these correlations were not large enough to explain all the differences between responses to the main question ${ }^{(7)}$. Now we know that PDTs differ mainly according to occupation, sex, and reference group. 


\subsection{Characteristics of the difference between groups}

In this section, we analyze the characteristics of between-group differences, namely, volume and tendencies. Especially, we want to know which group tends to accept the post-disaster activities in Table 1 earlier. The method is exemplified in Table 6. We calculated the accumulated percentage of respondents who answered "acceptable" at each time point for each activity and each group and then calculated differences between two groups at each time point. We counted the number of time points in which differences of $10 \%$ or more were found. In Table 6, there are ' 2 ' differences greater than $10 \%$ ('right after' and ' 1 week'). We summed this number for all 32 activities.

Because the differences of $10 \%$ or more between two groups are all positive (not negative) in Table 6, we see that those whose reference group is Japan accept the activity 'earlier' than those whose reference group is the disaster-affected area. In other words, the 'Japan' group includes more respondents who answered "acceptable" compared with the other group at the same time point.

Table 6. Example of a difference between groups

Activity: Commercials are broadcast on television.

\begin{tabular}{|c|c|c|c|c|c|c|}
\hline & Right after & 1 week & 1 month & 3 months & 6 months & $\begin{array}{c}\text { More than } \\
6 \text { months }\end{array}$ \\
\hline Japan (A) & $34.3 \%$ & $50.2 \%$ & $69.5 \%$ & $83.6 \%$ & $92.0 \%$ & $100.0 \%$ \\
\hline $\begin{array}{c}\text { The disaster- } \\
\text { affected area (B) }\end{array}$ & $24.0 \%$ & $35.9 \%$ & $61.1 \%$ & $80.5 \%$ & $95.2 \%$ & $100.0 \%$ \\
\hline Difference (A-B) & $10.3 \%$ & $14.3 \%$ & $8.4 \%$ & $3.0 \%$ & $-3.2 \%$ & $0.0 \%$ \\
\hline \\
$\uparrow 10 \%$
\end{tabular}

Table 7 shows the results of the analysis. We analyzed the groups that had relatively large effects on the differences in PDTs found in the previous section.

We found that differences depending on the reference group were larger than those depending on other groups regarding the absolute value of the differences. We also found that public employees, company employees, males, and those whose reference group is Japan tend to believe that activities are acceptable earlier than other groups because the differences were all positive. Interestingly, there was no negative difference of $10 \%$ or more. The nonexistence of negative differences means that the difference in PDTs does not differ according to activity; indeed, for nearly every activity, the tendencies of differences were the same (Figure 2). 
Table 7. Analysis of differences in PDTs between two groups (number of time points in which differences of $10 \%$ or more were found)

\begin{tabular}{|c|c|c|c|c|c|}
\hline & & $\begin{array}{c}10 \%- \\
15 \%\end{array}$ & $\begin{array}{c}15 \%- \\
20 \%\end{array}$ & $>20 \%$ & $\begin{array}{l}\text { Which group } \\
\text { accepts earlier? }\end{array}$ \\
\hline \multirow{3}{*}{ Occupation } & $\begin{array}{l}\text { Public employees and company } \\
\text { employees }\end{array}$ & 1 & 0 & 0 & Public employees \\
\hline & Public employees and others & 46 & 3 & 3 & Public employees \\
\hline & Company employees and others & 28 & 4 & 0 & $\begin{array}{l}\text { Company } \\
\text { employees }\end{array}$ \\
\hline & Sex (male, female) & 27 & 2 & 0 & Males \\
\hline \multirow{3}{*}{$\begin{array}{l}\text { Reference } \\
\text { group }\end{array}$} & Japan and disaster-affected area & 35 & 24 & 22 & Japan \\
\hline & $\begin{array}{l}\text { Japan and Aichi Prefecture or one's } \\
\text { local community }\end{array}$ & 49 & 37 & 10 & Japan \\
\hline & $\begin{array}{c}\text { Disaster-affected area and Aichi } \\
\text { Prefecture or one's local community }\end{array}$ & 0 & 0 & 0 & \\
\hline
\end{tabular}

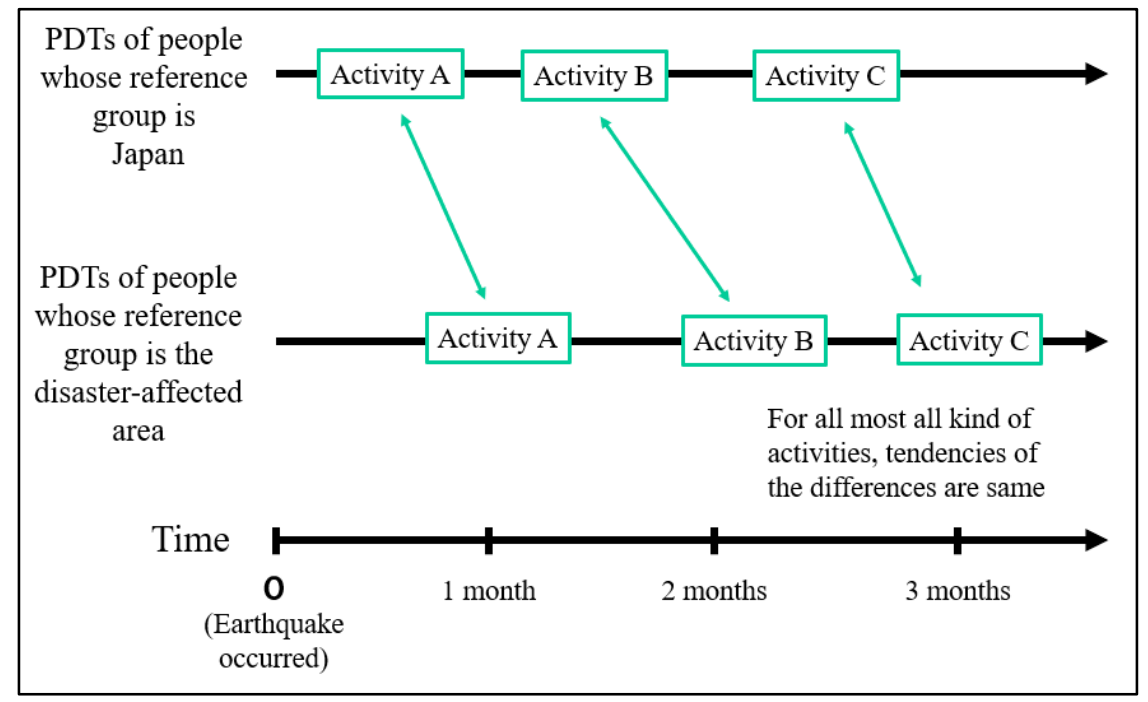

Figure 2. Simplified illustration of differences in PDTs between groups

\subsection{Estimation of PDTs in Aichi Prefecture as a whole}

The distributions of samples we obtained were not the same as the actual distributions of the population of Aichi Prefecture. Therefore, in this section, we adjust the distributions we obtained according to the actual distributions based on census data collected and reported by the Japanese government. In particular, we adjusted for occupation and sex, which were found 
to have relatively large impacts on the differences in PDTs, and then calculated the PDTs of Aichi Prefecture as a whole ${ }^{(8)}$. The results are shown in Table 8.

Table 8. Estimated PDTs of Aichi Prefecture as a whole

\begin{tabular}{|c|c|c|c|c|c|c|c|c|}
\hline \multirow{3}{*}{ E } & \multirow{3}{*}{$\begin{array}{l}\text { A waterworks bureau prioritizes the restoration of water service to an economically } \\
\text { important area } \\
\text { Local governments issue an alert for typhoons and heavy rains in their } \\
\text { local newsletter }\end{array}$} & \multirow{2}{*}{$\begin{array}{r}\text { Right after } \\
31.7 \%\end{array}$} & \multirow{2}{*}{$\begin{array}{l}1 \text { week } \\
50.4 \%\end{array}$} & \multicolumn{3}{|c|}{1 month 3 months6 months } & \multirow{2}{*}{$\begin{array}{c}\begin{array}{c}\text { More } \\
\text { than } \\
6 \text { months }\end{array} \\
100.0 \%\end{array}$} & \multirow{2}{*}{$\begin{array}{c}\text { Group } \\
1\end{array}$} \\
\hline & & & & $75.4 \%$ & $87.9 \%$ & $96.1 \%$ & & \\
\hline & & $32.1 \%$ & $43.9 \%$ & $71.7 \%$ & $86.6 \%$ & $96.8 \%$ & $100.0 \%$ & 2 \\
\hline E & Commercials are broadcast on television & $24.9 \%$ & $37.2 \%$ & $62.3 \%$ & $81.7 \%$ & $93.6 \%$ & $100.0 \%$ & 3 \\
\hline E & $\begin{array}{l}\text { A major firm in the area requests earlier repair works of the approaching roads to } \\
\text { the company's site }\end{array}$ & $22.5 \%$ & $36.3 \%$ & $62.0 \%$ & $79.4 \%$ & $93.4 \%$ & $100.0 \%$ & 3 \\
\hline E & $\begin{array}{l}\text { Volunteer groups begin to help not only affected households but also } \\
\text { affected firms }\end{array}$ & $20.9 \%$ & $37.6 \%$ & $62.3 \%$ & $79.4 \%$ & $95.1 \%$ & $100.0 \%$ & 3 \\
\hline \multirow[t]{5}{*}{ E } & $\begin{array}{l}\text { Local economic federations submit a letter of request for support with economic } \\
\text { recovery activities to the government }\end{array}$ & $20.5 \%$ & $32.2 \%$ & $58.8 \%$ & $81.4 \%$ & $97.1 \%$ & $100.0 \%$ & 3 \\
\hline & $\begin{array}{l}\text { Local governments close small shelters, and the residents there are asked to move } \\
\text { to a larger shelter }\end{array}$ & $15.4 \%$ & $26.7 \%$ & $50.3 \%$ & $74.3 \%$ & $92.8 \%$ & $100.0 \%$ & 4 \\
\hline & Broadcasting of comedy shows on television resumes & $14.0 \%$ & $27.9 \%$ & $51.4 \%$ & $73.5 \%$ & $93.3 \%$ & $100.0 \%$ & 4 \\
\hline & $\begin{array}{l}\text { Individuals sheltering in school classrooms are asked to move to the gym by the } \\
\text { local government in order to resume the classes }\end{array}$ & $11.3 \%$ & $22.4 \%$ & $52.2 \%$ & $79.6 \%$ & $95.6 \%$ & $100.0 \%$ & 5 \\
\hline & A charity music festival is held to lift the spirits of disaster-affected individuals & $13.1 \%$ & $24.0 \%$ & $51.2 \%$ & $72.1 \%$ & $94.5 \%$ & $100.0 \%$ & 6 \\
\hline E & $\begin{array}{l}\text { Local governments reduce the number of officers for shelters and local } \\
\text { residents and reassign them to assist with economic recovery efforts }\end{array}$ & $15.6 \%$ & $24.5 \%$ & $46.7 \%$ & $69.0 \%$ & $91.8 \%$ & $100.0 \%$ & 7 \\
\hline \multirow[t]{4}{*}{ E } & The prime minister calls for the quick restart of automobile exports & $13.8 \%$ & $21.7 \%$ & $46.0 \%$ & $71.6 \%$ & $90.7 \%$ & $100.0 \%$ & 7 \\
\hline & $\begin{array}{l}\text { A TV station in Tokyo broadcasts a program on the likelihood for Tokyo to be struck } \\
\text { by an earthquake in the near future }\end{array}$ & $13.5 \%$ & $20.3 \%$ & $40.6 \%$ & $58.3 \%$ & $83.4 \%$ & $100.0 \%$ & 7 \\
\hline & The provision of food and bathing facilities by the Self-Defense Forces ends & $12.9 \%$ & $16.4 \%$ & $32.2 \%$ & $59.8 \%$ & $86.1 \%$ & $100.0 \%$ & 7 \\
\hline & Local governments finalize the city's reconstruction plan & $12.7 \%$ & $21.1 \%$ & $41.3 \%$ & $65.8 \%$ & $93.5 \%$ & $100.0 \%$ & 7 \\
\hline \multirow[t]{2}{*}{ E } & $\begin{array}{l}\text { A major firm in the area engages in business with a company in another area } \\
\text { rather than a local company to resume normal operations more quickly }\end{array}$ & $12.5 \%$ & $19.1 \%$ & $40.9 \%$ & $62.8 \%$ & $82.4 \%$ & $100.0 \%$ & 7 \\
\hline & A celebrity uploads photos of their elaborate birthday party on social media & $12.1 \%$ & $17.3 \%$ & $34.1 \%$ & $54.0 \%$ & $75.7 \%$ & $100.0 \%$ & 7 \\
\hline E & A manufacturing company asks all its employees to return to work & $11.2 \%$ & $22.0 \%$ & $44.2 \%$ & $67.8 \%$ & $90.2 \%$ & $100.0 \%$ & 7 \\
\hline \multirow[t]{5}{*}{ E } & $\begin{array}{l}\text { A major firm decides to leave the affected area to resume normal operations more } \\
\text { quickly }\end{array}$ & $11.1 \%$ & $17.3 \%$ & $33.4 \%$ & $52.0 \%$ & $77.9 \%$ & $100.0 \%$ & 7 \\
\hline & The prime minister makes a state visit to a foreign country & $10.6 \%$ & $17.5 \%$ & $40.2 \%$ & $59.2 \%$ & $82.0 \%$ & $100.0 \%$ & 7 \\
\hline & $\begin{array}{l}\text { Interviews of disaster-affected individuals are conducted to learn lessons of } \\
\text { from the disaster }\end{array}$ & $10.5 \%$ & $19.5 \%$ & $41.7 \%$ & $61.8 \%$ & $90.6 \%$ & $100.0 \%$ & 7 \\
\hline & Local governments hold workshops to develop the city's reconstruction plan & $9.5 \%$ & $15.8 \%$ & $34.7 \%$ & $62.9 \%$ & $91.4 \%$ & $100.0 \%$ & 7 \\
\hline & A professional baseball game is held in the affected area & $8.8 \%$ & $13.9 \%$ & $35.0 \%$ & $55.3 \%$ & $83.0 \%$ & $100.0 \%$ & 7 \\
\hline E & A company makes large-scale personnel changes (such as transfers or layoffs) & $7.2 \%$ & $13.0 \%$ & $29.8 \%$ & $52.4 \%$ & $80.3 \%$ & $100.0 \%$ & 7 \\
\hline E & Construction of the Linear Chuo Shinkansen maglev line resumes & $9.4 \%$ & $16.1 \%$ & $31.1 \%$ & $47.6 \%$ & $79.9 \%$ & $100.0 \%$ & 8 \\
\hline E & A tourism campaign for affected areas is launched & $8.2 \%$ & $14.2 \%$ & $28.2 \%$ & $48.6 \%$ & $80.2 \%$ & $100.0 \%$ & 8 \\
\hline E & Automotive dealerships launch a sales promotion campaign & $7.1 \%$ & $11.6 \%$ & $29.4 \%$ & $47.7 \%$ & $79.6 \%$ & $100.0 \%$ & 8 \\
\hline \multirow[t]{2}{*}{ E } & Local governments end the free distribution of food and daily necessities at shelters & $7.0 \%$ & $13.4 \%$ & $27.9 \%$ & $48.8 \%$ & $80.6 \%$ & $100.0 \%$ & 8 \\
\hline & Governments reduce the number of people working to find missing persons & $6.0 \%$ & $10.3 \%$ & $24.0 \%$ & $41.8 \%$ & $76.7 \%$ & $100.0 \%$ & 8 \\
\hline \multirow[t]{3}{*}{ E } & Pachinko parlors reopen & $10.2 \%$ & $16.5 \%$ & $32.3 \%$ & $49.6 \%$ & $72.6 \%$ & $100.0 \%$ & 9 \\
\hline & Disaster-related trash collection service ends & $9.8 \%$ & $14.4 \%$ & $25.8 \%$ & $38.7 \%$ & $64.5 \%$ & $100.0 \%$ & 9 \\
\hline & Local governments hold an election for members of the prefectural assembly & $6.5 \%$ & $10.2 \%$ & $22.4 \%$ & $42.3 \%$ & $74.7 \%$ & $100.0 \%$ & 9 \\
\hline
\end{tabular}

Values are the percentage of respondents who answered "acceptable" to the main question for each time point. "E" indicates economic activities shown in Table 1. Cells with values less than $25 \%$ are colored red, $25 \%-50 \%$ are orange, $50 \%-75 \%$ are yellow, and greater than $75 \%$ are blue. "Group" means groups that are defined by combinations of 25 th percentile value, 50th percentile value, and 75 th percentile value ${ }^{(9)}$. Group 1 indicates activities that are socially acceptable at the earliest stage of the disaster recovery, and group 9 indicates those that are socially acceptable at the final stage of the disaster recovery. 
The results indicate that socially acceptable time points differ according to the activity. It is important to note that economic activities are not concentrated at the bottom of Table 7 (group 8 or 9) but are distributed widely from the earlier stages (group 1, 2, or 3) to the later stages of the recovery phase. The above trend indicates that some economic activities are socially acceptable at the earlier stages, including "A waterworks bureau prioritizes the restoration of water service to an economically important area (group 1)" and "A major firm in the area requests earlier repair works of the approaching roads to the company's site (group 3)." Accordingly, we consider that infrastructure recovery should be prioritized, taking into account the economic recovery of this area. If we want to avoid public backlash from attempting early efforts aimed at economic recovery, the order of conducting the economic activities can be determined by referencing Table 8 .

\section{DISCUSSION}

The survey results revealed the characteristics of PDTs in the study area. PDTs differ according to sex, occupation, and reference group rather than location, age, household members, and household income. The PDTs of public employees, company employees, males, and those whose reference group is Japan are generally earlier than those of other people. We also estimated the PDTs of Aichi Prefecture as a whole and found that some kinds of economic activities are socially acceptable in the earlier stages of the disaster recovery (e.g., "A waterworks bureau prioritizes the restoration of water service to an economically important area.", "Commercials are broadcast on television.", "A major firm in the area requests earlier repair works of the approaching roads to the company's site.", "Volunteer groups begin to help not only affected households but also affected firms." and "Local economic federations submit a letter of request for support with economic recovery activities to the government."). Although the actual reasons for accepting these activities in the earlier stage are unknown from the survey data, we conjecture that people in Aichi Prefecture generally recognize contributions of manufacturing to their daily lives and accept to distribute recovery resources to economic recovery.

It is important to note that PDTs are not a single timeline but rather multiple timelines. Accordingly, the PDTs of Aichi Prefecture consist of an aggregation of each person's PDT, which differ according to the individual or group. Hence, we refer to multiple PDTs.

The findings of this study can be applied in two ways.

The first use is for consensus-building on a better recovery process in the area. If only the PDTs of Aichi Prefecture as a whole were followed, small and medium-sized firms would likely have difficulty maintaining adequate cash flow because such companies lack the money to survive beyond one month after a disaster. Although the Small and Medium Enterprise Agency (2012) recommends that firms have reserves for one month as part of their business 
continuity plan (BCP), many cannot easily secure that amount. Furthermore, we know that a large company in the area set 1 month as its target for restarting production (i.e., recovery time objective) in its BCP. In contrast, in the PDTs of Aichi Prefecture, for example, "The prime minister calls for the quick restart of automobile exports" was acceptable to $46 \%$ of the population at one month after the earthquake. However, if the government were to follow the other 54\% and postpone support for the economic recovery, many small and medium-sized firms would have difficulty surviving. The large company mentioned above may not be able to achieve its recovery time objective. We consider that the people of Aichi Prefecture need to discuss this kind of problem. If we host a workshop where residents with different PDTs can gather, the discussion may lead to a pre-disaster recovery plan acceptable to many people. Suppose such a discussion is held only within the government (public employees) or at private firms (company employees). In that case, a consensus may be reached quickly because there are few differences in PDTs, but the majority of the public may not accept it. According to the reference group, we know that there are differences in PDTs. Therefore, people in the central government whose responsibility is to consider policies for Japan and those in local governments whose responsibility is to consider policies for their area need to collaborate on pre-disaster recovery planning. These points above should be included in guidelines on predisaster recovery planning focused on short- to medium-range activities for recovery. In addition, in the field of science and technology studies, there is an idea of "mini-publics" (Ryan and Smith 2014), which involves randomly sampling people to create groups for holding deep discussions of a given topic. We can utilize the knowledge on the differences in PDTs produced in the present study to make better "mini-publics" in which diverse opinions on the recovery process can be exchanged.

Additionally, the authors have already begun to hold a series of workshops on the recovery process in this area and plan to use the findings from the present survey going forward. As one example, when we organized the first trial workshop, we took care to have an appropriate ratio of male and female participants because generally, there are differences in PDTs between the sexes.

Another way to utilize the findings of this survey is to promote consideration of the existence of people who have different and diverse PDTs. It is very difficult to reach a perfect consensus because it is nearly impossible for all stakeholders to participate in the process, and the actual disaster may differ substantially from the one that was predicted. Some people may have no choice but to participate in activities even when they are not socially acceptable to others. In such cases, those engaged in recovery activities may choose better words when they need to communicate with the public if they know the PDTs of Aichi Prefecture as a whole and keep in mind that there are differences in PDTs between people. Choosing thoughtful words reduce any potential backlash.

Finally, to assess the validity of the findings and evaluate whether the survey method is appropriate, we compared the survey results with similar large-scale disasters, namely, the 1995 Great Hanshin Earthquake and the 2011 Great East Japan Earthquake. In response to the 
activity "Local governments hold an election for members of the prefectural assembly," 42.3\% of respondents answered that it was acceptable at three months and $74.7 \%$ at six months. Following the Great East Japan Earthquake, the prefectural assembly election in Miyagi Prefecture was postponed (Ministry of Internal Affairs and Communications 2011) until nearly eight months after the earthquake (Miyagi Prefectural Government 2012). We could find no record of public objections to holding the election at the rescheduled time, so we can assume that most people accepted this activity, which is in line with the present study results. As another example, Hyogo Prefecture finalized its reconstruction plan just two months after the Great Hanshin Earthquake, leading to a strong public backlash (National Land Agency 1999). In our survey, $41.3 \%$ of respondents answered that finalizing reconstruction plans were acceptable at one month and $65.8 \%$ at 3 months, so we can assume that such an activity is not acceptable to most people at two months.

Considering the two abovementioned comparisons, our survey results can be regarded as reliable for revealing the PDTs in the study area. The reliability of the survey results indicates the appropriateness of our survey method. Although the survey was conducted based on a single disaster scenario, it is not a problem for revealing characteristics of PDTs in a target area. Blackouts, water and gas supply disruption, and evacuation to temporary housing will occur in most large-scale disasters. If we consider, for example, "3 months" in the present scenario as "the time when the water and gas supply are restored" and " 6 months" as "the time when people will move to temporary housing," then the generalizability of the survey results increases. Accordingly, we consider that our method for surveying PDTs was appropriate.

\section{CONCLUSIONS}

This study surveyed PDTs in the most industrialized prefecture in Japan and identified many related characteristics in the area. We also evaluated our survey method was appropriate for revealing PDTs in a target area. Surveying PDTs and designing a consensus process by considering the differences in PDTs among different groups of people are important for predisaster recovery planning focused on short- to medium-range activities for recovery.

We will focus on differences in PDTs between prefectures in future research by conducting a survey in another area. Considering the importance of the reference groups, we will investigate the thought processes that lead to the selection of reference groups. We will also continue our workshops for pre-disaster recovery planning in the study area with reference to the present results. Doing so will help us more fully understand the differences in PDTs and find new ways of building consensus. 


\section{ACKNOWLEDGEMENT}

This study was supported by a grant from the Cross-ministerial Strategic Innovation Promotion Program of the Cabinet Office, Japan. We also sincerely appreciate insightful comments from anonymous reviewers.

\section{FOOTNOTES}

(1) For example, in the 1995 Great Hanshin Earthquake in Japan, the city's reconstruction plan was finalized two months after the earthquake. There was a strong public backlash due to the lack of citizen participation in the process (National Land Agency 1999).

(2) Takahashi et al. (2016) proposed the same kind of idea and tried to develop a pre-disaster recovery plan of road networks in Kagawa Prefecture, Japan by using a mathematical modeling approach.

(3) Industrial firms in Aichi Prefecture contribute about 48.7 trillion yen to the Japanese economy, which is the largest of all 47 prefectures. (Ministry of Economy, Trade and Industry 2020)

(4) In this area, certain roads have been designated as critical to disaster response, so it is a priority to reopen these roads within 7 days after an earthquake (Chubu-region Main Roads Council 2020). However, there are no agreements regarding priorities for other roads and infrastructure.

(5) We do not intend to insist that the recovery process should be determined by social norms alone. Such reliance on social norms would lead to many problems. We discuss this point in the Discussion section.

(6) When making groups based on sex, we excluded samples who answered "others." When making groups based on the reference group, we combined the responses "Aichi Prefecture" and "one's local community" as a single category for the statistical analysis to ensure a sufficient number of samples. The two answers have similar meanings because the survey was conducted of residents of Aichi Prefecture and their local community would be within the prefecture. Additionally, we excluded samples who answered "others" to the reference group question.

(7) First, the samples in this survey have a different proportion of sexes in each occupation. We checked the statistical difference between sexes in the occupation category "others." (We were unable to perform the same analysis for public employees and company employees due to an insufficient number of samples.) The numbers of statistical differences between male and female respondents by the chi-squared test were $9(\mathrm{p}<0.1), 4(\mathrm{p}<0.05)$, and $1(\mathrm{p}<0.01)$. Compared with Table 5, the numbers of statistical differences between the sexes were smaller but some still exist. 
Second, we checked relationships between reference group and sex and between reference group and occupation. We conducted the chi-squared test. There was no statistical relationship between the reference groups and the sexes $(\mathrm{p}=0.678$; we excluded "others" from both categories) but there was a statistical relationship between the reference groups and the occupations ( $\mathrm{p}=0.023$; we excluded "others" from the reference group category). However, as in Table 9, there was not a strong relationship between the reference groups and the occupations.

Table 9. Cross tabulation of reference group and occupation

\begin{tabular}{|c|c|c|c|c|c|c|}
\hline & Japan & $\begin{array}{c}\text { The disaster- } \\
\text { affected area }\end{array}$ & $\begin{array}{c}\text { Aichi } \\
\text { Prefecture }\end{array}$ & $\begin{array}{c}\text { One's local } \\
\text { community }\end{array}$ & Others & Total \\
\hline $\begin{array}{c}\text { Public } \\
\text { employee }\end{array}$ & $\begin{array}{c}36 \\
(17 \%)\end{array}$ & $\begin{array}{c}59 \\
(18 \%)\end{array}$ & $\begin{array}{c}30 \\
(25 \%)\end{array}$ & $\begin{array}{c}23 \\
(29 \%)\end{array}$ & $\begin{array}{c}2 \\
(40 \%)\end{array}$ & $\begin{array}{c}150 \\
(20 \%)\end{array}$ \\
\hline $\begin{array}{c}\text { Company } \\
\text { employee }\end{array}$ & $\begin{array}{c}99 \\
(46 \%)\end{array}$ & $\begin{array}{c}130 \\
(39 \%)\end{array}$ & $\begin{array}{c}37 \\
(31 \%)\end{array}$ & $\begin{array}{c}32 \\
(40 \%)\end{array}$ & $\begin{array}{c}2 \\
(40 \%)\end{array}$ & $\begin{array}{c}300 \\
(40 \%)\end{array}$ \\
\hline Others & 78 & 145 & 51 & 25 & 1 & 300 \\
$(37 \%)$ & $(43 \%)$ & $(43 \%)$ & $(31 \%)$ & $(20 \%)$ & $(40 \%)$ \\
\hline Total & 213 & 334 & 118 & 80 & 5 & 750 \\
\hline
\end{tabular}

The percentages are the proportions of occupations in each reference group.

(8) The adjustment method is shown in Figure 3.

Census data (2015)
\begin{tabular}{|l|r|r|l|l|}
\hline & $\begin{array}{l}\text { Public } \\
\text { employee }\end{array}$ & $\begin{array}{l}\text { Company } \\
\text { employee }\end{array}$ & Others & Total \\
\hline Male & 60925 & 1476309 & 2203610 & 3740844 \\
\hline Female & 26604 & 576367 & 3139313 & 3742284 \\
\hline Total & 87529 & 2052676 & 5342923 & 7483128 \\
\hline
\end{tabular}

Proportions
\begin{tabular}{|l|r|r|l|r|}
\hline & $\begin{array}{l}\text { Public } \\
\text { employee }\end{array}$ & $\begin{array}{l}\text { Company } \\
\text { employee }\end{array}$ & Others & Total \\
\hline Male & 0.008142 & 0.197285 & 0.294477 & 0.499904 \\
\hline Female & 0.003555 & 0.077022 & 0.419519 & 0.500096 \\
\hline Total & 0.011697 & 0.274307 & 0.713996 & 1 \\
\hline
\end{tabular}

The samples

\begin{tabular}{|l|r|r|l|l|}
\hline & $\begin{array}{l}\text { Public } \\
\text { employee }\end{array}$ & $\begin{array}{l}\text { Company } \\
\text { employee }\end{array}$ & Others & \multicolumn{1}{l|}{ Total } \\
\hline Male & 125 & 235 & 137 & 497 \\
\hline Female & 25 & 64 & 162 & 251 \\
\hline Total & 150 & 299 & 299 & 748 \\
\hline
\end{tabular}

Proportions
\begin{tabular}{|l|r|r|l|r|}
\hline & $\begin{array}{l}\text { Public } \\
\text { employee }\end{array}$ & $\begin{array}{l}\text { Company } \\
\text { employee }\end{array}$ & Others & Total \\
\hline Male & 0.167112 & 0.314171 & 0.183155 & 0.664439 \\
\hline Female & 0.033422 & 0.085561 & 0.216578 & 0.335561 \\
\hline Total & 0.200535 & 0.399733 & 0.399733 & 1 \\
\hline
\end{tabular}

Weights for the adjustment

\begin{tabular}{|l|r|r|l|r|}
\hline & $\begin{array}{l}\text { Public } \\
\text { employee }\end{array}$ & $\begin{array}{l}\text { Company } \\
\text { employee }\end{array}$ & Others & Total \\
\hline Male & 0.04872 & 0.627954 & 1.607802 & 0.75237 \\
\hline Female & 0.106372 & 0.900197 & 1.937037 & 1.490327 \\
\hline Total & 0.058328 & 0.686227 & 1.786184 & 1 \\
\hline
\end{tabular}

Figure 3. Calculation of a weights table for the adjustment 
The upper left table presents census data from Aichi Prefecture and the upper right table presents their proportions. We divided the values from the census proportion table by the values from the sample proportion table in order to create the weights table. We multiplied the weights by each sample to obtain the PDTs for Aichi Prefecture as a whole.

(9) The definitions of each group in Table 8 are presented in Table 10.

Table 10. Relationships between the groups and percentile values

\begin{tabular}{|c|c|c|c|}
\hline Group no. & 25 th percentile value & 50th percentile value & 75th percentile value \\
\hline 1 & $\begin{array}{l}\text { right after the } \\
\text { earthquake }\end{array}$ & $\begin{array}{l}1 \text { week after the } \\
\text { earthquake }\end{array}$ & $\begin{array}{l}1 \text { month after the } \\
\text { earthquake }\end{array}$ \\
\hline 2 & $\begin{array}{l}\text { right after the } \\
\text { earthquake }\end{array}$ & $\begin{array}{l}1 \text { month after the } \\
\text { earthquake }\end{array}$ & $\begin{array}{c}3 \text { months after the } \\
\text { earthquake }\end{array}$ \\
\hline 3 & $\begin{array}{l}1 \text { week after the } \\
\text { earthquake }\end{array}$ & $\begin{array}{l}1 \text { month after the } \\
\text { earthquake }\end{array}$ & $\begin{array}{c}6 \text { months after the } \\
\text { earthquake }\end{array}$ \\
\hline 4 & $\begin{array}{l}1 \text { week after the } \\
\text { earthquake }\end{array}$ & $\begin{array}{l}1 \text { month after the } \\
\text { earthquake }\end{array}$ & $\begin{array}{l}6 \text { months after the } \\
\text { earthquake }\end{array}$ \\
\hline 5 & $\begin{array}{l}1 \text { month after the } \\
\text { earthquake }\end{array}$ & $\begin{array}{l}1 \text { month after the } \\
\text { earthquake }\end{array}$ & $\begin{array}{l}3 \text { months after the } \\
\text { earthquake }\end{array}$ \\
\hline 6 & $\begin{array}{l}1 \text { month after the } \\
\text { earthquake }\end{array}$ & $\begin{array}{l}1 \text { month after the } \\
\text { earthquake }\end{array}$ & $\begin{array}{l}6 \text { months after the } \\
\text { earthquake }\end{array}$ \\
\hline 7 & $\begin{array}{l}1 \text { month after the } \\
\text { earthquake }\end{array}$ & $\begin{array}{l}3 \text { months after the } \\
\text { earthquake }\end{array}$ & $\begin{array}{c}6 \text { months after the } \\
\text { earthquake }\end{array}$ \\
\hline 8 & $\begin{array}{l}1 \text { month after the } \\
\text { earthquake }\end{array}$ & $\begin{array}{c}6 \text { months after the } \\
\text { earthquake }\end{array}$ & $\begin{array}{l}6 \text { months after the } \\
\text { earthquake }\end{array}$ \\
\hline 9 & $\begin{array}{l}1 \text { month after the } \\
\text { earthquake }\end{array}$ & $\begin{array}{l}6 \text { months after the } \\
\text { earthquake }\end{array}$ & $\begin{array}{l}\text { more than } 6 \text { months } \\
\text { after the earthquake }\end{array}$ \\
\hline
\end{tabular}

\section{REFERENCES}

AERA (2020) Policies for COVID-19 are in a maze; conflicts between epidemic prevention and economic recovery are getting more severe. July 27: 22. (in Japanese)

Aichi Prefectural Government (2014) A report on damage estimations of earthquakes in Aichi prefecture. (in Japanese) https://www.pref.aichi.jp/bousai/2014higaiyosoku/whiteb ooknew2.pdf 
Aichi Prefectural Government (2020) Cities, towns and villages in prefecture. (in Japanese) https://www.pref.aichi.jp/site/userguide/link-citytown.html

Bryant, R. A (2006) Recovery after the tsunami: Timeline for rehabilitation. The Journal of Clinical Psychiatry, 67 (Suppl 2): 50-55.

Cabinet Office (2019) A report on quantitative damage estimations of Nankai megathrust earthquakes in each prefecture (damages on facilities). (in Japanese) http://www.bousai. go.jp/jishin/nankai/taisaku_wg/pdf/2_sanko.pdf

Central Disaster Management Council (2013) A second report on scenario-based damage estimations of Nankai megathrust earthquakes in each prefecture (damages on facilities). (in Japanese) http://www.bousai.go.jp/jishin/nankai/nankaitrough_info.html http://www.bousai.go.jp/jishin/nankai/taisaku_wg/pdf/20130318_shiryo2_1.pdf

Chubu-region main roads council (2020) Road recovery strategy in Chubu-region "Kushinoha strategy". (in Japanese) https://www.cbr.mlit.go.jp/road/kanri-bunkakai/pd f/202006 kushinoha.pdf

Ito, T. and Kashima, H. (eds.) (2018) The 2016 Kumamoto Earthquake and The Regional Industries. Nippon Hyoron Sha: Japan, pp.171 (in Japanese)

Japan water works association (2008) A report on damages of water facilities in 2007 Niigata -Chuetsu-Oki earthquake. (in Japanese) http://www.jwwa.or.jp/houkokusyo/houkokusyo 08.html

Kamei, A (2011) The serious earthquake in the eastern Japan and public service advertising: Roles of advertising at a stricken time and effects of public service advertising on suffered consumers. The bulletin of the Graduate School of Commerce, 73: 1-14. (in Japanese)

Kimura, R. (2007) Recovery and reconstruction calendar. Journal of Disaster Research, 2 (6): 465-474.

Ministry of Economy, Trade and Industry (2018) Lessons from 2007 Niigata-Chuetsu-Oki earthquake and future disaster prevention plan; BCP as a basis of a continuous enterprises management. (in Japanese) https://www.chusho.meti.go.jp/koukai/kenkyuk ai/kyoujin/181226kyoujin.htm https://www.chusho.meti.go.jp/koukai/kenkyukai/kyouji n/2018/181226kyoujin06.pdf

Ministry of Economy, Trade and Industry (2020) Census of Manufacture 2019. (in Japanese) https:/www.meti.go.jp/statistics/tyo/kougyo/result-2/r01/kakuho/chiiki/index.html

Ministry of Education, Culture, Sports, Science and Technology (2020) A list of results of long-term evaluations on possibilities of earthquakes. (in Japanese) https://www.jishin. go.jp/main/choukihyoka/ichiran.pdf

Ministry of Health, Labour and Welfare (2007) An 11th report on damage and countermeasures in 2007 Niigata-Chuetsu-Oki earthquake. (in Japanese) https://www.mhlw.go.jp/houdou /2007/07/h0723-1.html

Ministry of Internal Affairs and Communications (2011) Elections and 2011 Great East Japan Earthquake. (in Japanese) https://www.soumu.go.jp/senkyo/chihou17 01.html

Ministry of Land, Infrastructure, Transport and Tourism (2018) A guideline for pre-disaster recovery planning. (in Japanese) https://www.mlit.go.jp/toshi/toshi_tobou_fr_000036.h $\underline{t \mathrm{ml}}$ 
Miyagi Prefectural Government (2012) An election of members of Miyagi prefectural assembly in November 13, 2011. (in Japanese) https://www.pref.miyagi.jp/site/miyagisenkyo-kekka/h23kengi.html

Miyamoto, T. and Atsumi T. (2011) Visualization of disaster revitalization processes collective construction of survivors' experiences in the 2004 Niigata Chuetsu Earthquake. Progress in Asian Social Psychology Series, 8: 307-323.

National Land Agency (1999) Lessons from Great Hanshin-Awaji earthquake. (in Japanese) http://www.bousai.go.jp/kyoiku/kyokun/hanshin_awaji/ http://www.bousai.go.jp/kyoiku/kyokun/hanshin awaji/data/detail/pdf/3-3-3.pdf

NHK (2020) 9 years have passed since the earthquake but still not fully recovered. A recovery and reconstruction calendar of 2,000 damaged people. (in Japanese) https://www3.nhk.or.jp/news/html/20200304/k10012311741000.html (expired)

Otsuyama, K. and Maki, N. (2018) A comparative analysis and identification on legislative systems for pre-disaster recovery planning in Japan and U.S. Journal of the City Planning Institute of Japan, 53 (2): 132-143. (mostly in Japanese) https://www.jstage. jst.go.jp/article/journalcpij/53/2/53 132/ article/-char/en

Ryan, M. and Smith, G. (2014) Defining Mini-Publics. In Grönlund, K., Bächtiger, A. and Setälä, M.(Eds.), Deliberative mini-publics: Involving citizens in the democratic process. ECPR Press: United Kingdom, 9-26.

Shibutani, T. (1955) Reference Groups as Perspectives. American Journal of Sociology, 60 (6): $562-569$.

Solnit, R. (2010) A Paradise Built in Hell -The Extraordinary Communities That Arise in disaster-. penguin: U.S., pp.368

Takahashi, K., Isouchi, C., Shiraki, W., Iwahara, H., Inomo, H. and Sato, E. (2016) Studying the strategic restoration schedule for Takamatsu area's road networks: The Nankai megathrust earthquakes' aftermath. Journal of Japan Society of Civil Engineers, Ser. F6 (Safety Problem), 72 (2): I_99-I_106. (mostly in Japanese) https://www.jstage.jst.go.jp/ article/jscejsp/72/2/72 I 99/article/-char/en

Tanaka, S., Hayashi, H. and Shigekawa, K. (1999) Behavior of Disaster Victims along the Course of Disaster Process. Journal of Japan Society for Natural Disaster Science, 18 (1): 21-29. (in Japanese)

The Asahi Shimbun (2020a) A travel promotion campaign is beginning but some people in sightseeing areas say prevention of spreading COVID-19 should be prioritized. July 15(morning edition): 7 (in Japanese)

The Asahi Shimbun (2020b) What do you think about the travel promotion campaign against COVID-19. October 14(morning edition): 12 (in Japanese)

The Small and Medium Enterprise Agency (2012) A guideline of BCP for small and medium enterprise. (in Japanese) https://www.chusho.meti.go.jp/bcp/contents/level a/bcpgl 05a 4.html

Yamanaka, S. (2005) Media in earthquake disasters. Sekaishisosha: Japan, pp.238 (in Japanese) 